UDK 821.163.42.09 Truhelka J.

Pregledni rad

Primljeno: 19.06.2020.

Odobreno za štampu: 01.07.2020.

DOI: https://doi.org/10.46630/gped.1.2020.02

\title{
SLIKA OBITELJI U KNJIŽEVNOJ TRILOGIJI ZLATNI DANCI JAGODE TRUHELKE
}

\author{
Maja Verdonik ${ }^{1}$, Josipa Kovač \\ Sveučilište u Rijeci, Učiteljski fakultet Republika Hrvatska
}

\begin{abstract}
Apstrakt: U radu se predstavlja značenje i uloga obitelji u književnoj trilogiji Zlatni danci jedne od začetnica hrvatske dječje realističke proze, ujedno i začetnice obiteljskog romana - Jagode Truhelke. Cilj rada je analizom dostupne literature i književnih tekstova prikazati književne motive prisutne u opisivanju slike obitelji u književnoj trilogiji Zlatni danci. Jagoda Truhelka upoznaje čitatelje sa svojim idiličnim djetinjstvom koje karakteriziraju obiteljski sklad, kršćanski duh u odgoju djece, domoljublje te međuzavisnost djece i roditelja. Riječ je o vrijednostima na kojima se, kao sastavnim komponentama, temelji analiza slike obitelji u Truhelkinim dječjim romanima, predstavljena u radu. Književna trilogija Zlatni danci prikazuje čvrsto strukturiranu, homogenu obitelj u kojoj je veliku ulogu imao otac - učitelj. Vjerska načela predstavljala su putokaz u odgoju djece, zasnovanom na kršćanskim načelima, prisutnima i u opisima vjerskih blagdana i običaja. Njegovanje domoljublja očituje se u svakidašnjim pripovijedanjima priča i u dječjim igrama pri čemu je otac još jednom bio onaj koji je u tome imao najvažniju ulogu. Dječja i roditeljska međuzavisnost prisutna je u trajnoj brizi članova obitelji jednih za druge, posebice $u$ trenutcima zapadanja djece u neprilike u situacijama u kojima roditelji nisu bili prisutni. Odrastanje u obitelji Jagode Truhelke bilo je sretno jer pružilo djeci ono što svako dijete zavrjeđuje: ljubav, pažnju, osjećaje sigurnosti, pripadnosti, nježnosti i poštovanja. Slika takve obitelji, predstavljena u književnoj trilogiji Zlatni danci, zasigurno i danas doprinosi odgoju suvremene djece čitatelja.
\end{abstract}

Ključne riječi: Jagoda Truhelka, Zlatni danci, hrvatski dječji roman, obitelj u dječjoj književnosti

\section{Uvod}

Dječja književnost sastavni je dio svake nacionalne književnosti. Ono što dječju književnost razlikuje od književnosti za odrasle jest tematika i forma koja odgovara dječjoj dobi, kao i sadržaj koji uključuje opis djetinjstva, dječje likove te djeci zanimljivu fabulu i igru. Kao što piše Stjepan Hranjec (2004), dječju književnost potrebno je promatrati uzimajući u obzir malog čitatelja odnosno dijete kao glavnog recipijenta književnog djela.

\footnotetext{
${ }^{1}$ mverdonik@ufri.uniri.hr
} 
Obitelj je osnovna ljudska zajednica u kojoj dijete razvija svoje prve fizičke i kognitivne sposobnosti te oblikuje sebe kao individuu. Uz pregled književnoteorijskih odrednica dječjeg romana kao žanra dječje književnosti te uvid u prisutnost teme obitelji u dječjem romanu, cilj rada je utvrditi književne pristupe Jagode Truhelke, jedne od začetnica hrvatskog dječjeg romana, u opisivanju slike obitelji i njezine uloge u životu djece u književnoj trilogiji Zlatni danci (1918-1944).

\section{Književnoteorijske odrednice dječjega romana}

Pojam dječji roman u hrvatskoj dječjoj književnosti prvi put se spominje u studiji Dječja književnost Milana Crnkovića, objavljenoj 1967. godine. Crnković razdvaja dva tipa dječjeg romana: roman o djetetu i djetinjstvu te romane o životinjama i pustolovne romane koje naziva takozvanim graničnim vrstama. Međutim, Berislav Majhut navodi kako Crnković dječjim romanom ne smatra bilo koji roman namijenjen djetetu (pustolovni, historijski, roman o životinjama i sl.), već samo onaj čiji su junaci djeca i koji se naziva romanom o djetinjstvu (Majhut, 2005).

O dječjem romanu postoje različita mišljenja i interpretacije ove književne strukture. Joža Skok definira dječji roman sljedećim riječima: „dječji roman je slojevita pripovjedna vrsta dječje književnosti u kojoj su glavni likovi djeca, sa svim svojim doživljajima, strepnjama i nadama" (Skok, 1991, prema Hranjec, 1998: 9).

Stjepan Hranjec (1998) ističe fabulu, likove, pustolovnost i akciju, te fenomen igre i jednostavnost kao glavne segmente dječjega romana. „Fabula u dječjem romanu nije toliko složeno strukturirana, likovi su najčešće predstavljeni u okviru družina gdje je glavni lik često i vođa te družine, pustolovnost i akcija pridonose dinamici, a fenomen igre neizostavan je i na tematskom planu i na razini stila" (Hranjec, 1998: 9-11).

Ono što dječji roman ili, kako ga autori Milan Crnković i Dubravka Težak (2002) određuju, roman o djetinjstvu mora imati jest opis djetinjstva. Mora sadržavati opise prizora iz stvarnog života te dječje avanture koje ne bi trebale prelaziti određene granice. Također, dječji roman odlikuje se kratkoćom, jednostavnošću stila i izraza te gotovo uvijek sretnim završetkom. Osim ovih karakteristika, radnja dječjeg romana najčešće je podijeljena na poglavlja (Crnković i Težak, 2002).

Berislav Majhut (2005) naglašava da dječji roman ne treba umanjivati i shvaćati ga jednostavnijom izvedenicom romana za odrasle koja je namijenjena slabijim djetetovim intelektualnim mogućnostima. Naprotiv, dječji roman posjeduje visok stupanj autonomije u odnosu na književnost uopće, on je dio drugog sustava, razvijao se u sklopu dječje književnosti te se u tom okviru određuju vrste i njegova obilježja.

Prema riječima Dubravke Zime (2011) dječji se roman u hrvatskoj književnosti do tridesetih godina 20. stoljeća podnaslovljavao kao pripovijest ili pripovijetka. Tijekom četrdesetih godina taj se termin pojavljivao još ponegdje u književnom stvaralaštvu, dok se kasnije takva praksa gubi. „U hrvatskom kontekstu termin dječji roman postaje referentan od 30-ih godina 20 . stoljeća kada se na produkcijskoj razini afirmira kao oznaka za dulji prozni tekst razvedenije fabularne i narativne organizacije" (Hameršak i Zima, 2015: 202). 
U jednoj od novijih studija o hrvatskom dječjem romanu Sanja Vrcić-Mataija uspostavlja tipologiju romana realističkog pripovjednog modela temeljem odnosa fikcije i fakcije. Autorica pritom uvažava dobni kriterij recipijenata i književnih junaka, stupanj modernosti oblikovnih postupaka te prevladavajuće narativne figure. Potonje drži ključnim kriterijem u određenju specifičnih tipova dječjeg romana 90-ih godina 20. stoljeća i iz njih proizašlih podtipova i oblika, zasnovanih na kulturološkoj slici djetinjstva i odrastanja promatranog u okvirima prostorno-vremenskog toposa (Vrcić-Mataija, 2018).

\section{Motiv obitelji u dječjoj književnosti}

Obitelj je, kao što piše Josip Janković: „kolijevka čovjeka i čovječanstva” (2004: 13). Obitelj se smatra jednom od najstarijih društvenih institucija te je poput ljudskoga društva tijekom povijesti, razvijajući se, doživljavala brojne promjene u strukturi. „Gospodarski, socijalni i moralni kontekst suvremenog društva izaziva značajne promjene unutar obitelji” (Maleš, 2012: 13), stoga je danas teško pronaći jednoznačno i jedinstveno određenje obitelji.

U obitelji dijete stječe iskustva o ljudima, o njihovim odnosima, upoznaje sebe i svoje vrijednosti te svoj položaj u društvu. Ta iskustva čine temeljnu točku u psihičkom razvoju ljudske jedinke pa tako i svakog djeteta. „Stoga je i krug kretanja djeteta i njegov interes iskazan u dječjoj literaturi često vezan za obitelj, mada je tijekom razvoja hrvatske dječje književnosti proširenje dječjeg vidokruga i davanje društvene širine dječjim pogledima dovelo i do zapostavljanja obitelji i drugih strana intimnog života dječje ličnosti odnosno do nedovoljnog sklada između intimnog, osobnog, obiteljskog i društvenog" (Prodan, 2005: 7).

U dječjoj književnosti tema obitelji često je zastupljena te se može reći, kao što zaključuje Ivan J. Bošković, da je obitelj u hrvatskoj dječjoj književnosti „nepotrošena književna inspiracija" (2005: 25). Iako motiv obitelji ponekad nije u prvome planu, može se ipak pronaći u gotovo svakom književnom djelu namijenjenom djetetu. U dječjoj književnosti pojavljuju se djeca, najmlađi članovi obitelji, kao glavni likovi stoga je tema obitelji u književnim djelima namijenjenim djeci veoma suvremena, odnosno atraktivna i aktualna te štoviše potrebna književnosti (Hranjec, 2009).

\subsection{Motiv obitelji u hrvatskom dječjem romanu}

Tema obitelji u dječjoj književnosti tumačena je multidisciplinarno. Moguće ju je promatrati ne samo u smislu društvene uvjetovanosti, već i povijesno-kulturološki i tipološki. Stjepan Hranjec (2009), pišući o obitelji u hrvatskome dječjem romanu, predlaže nekoliko modela književno oblikovanih obiteljskih zajednica. To su: „čvrsto strukturirana homogena obitelj, socijalno-staleška obiteljska zajednica, luckasta obitelj, krnja obitelj, razorena obiteljska zajednica, supstitucijska obitelj, urbana formalna obitelj, obitelj u humorno-fantazijskom svijetu i slično" (Hranjec, 2009: 101). 
U hrvatskoj dječjoj književnosti afirmirao se tip obiteljskog romana, čija je začetnica, uz Ivanu Brlić-Mažuranić 2 , Jagoda Truhelka. Njezina književna trilogija Zlatni danci primjer je ciklusa dječjih romana u kojima Književnica prikazuje čvrsto strukturiranu homogenu obitelj kroz opise vlastitog odrastanja u obiteljskom domu. „U Zlatnim dancima osjećamo toplinu doma i ljubav, unatoč mjestimičnim nesuglasicama između roditelja i djece i braće i sestara" (Hranjec, 2009: 102). U svojem književnom stvaralaštvu Jagoda Truhelka naglašava važnost obitelji i njezinog zdravog funkcioniranja te je tom tematikom postala istaknuta književna osobnost u razvoju hrvatskog dječjeg romana.

\section{Jagoda Truhelka}

Jagoda Truhelka (Osijek, 1864. - Zagreb, 1957), hrvatska književnica i učiteljica, bila je i pedagoška teoretičarka i aktivistica u borbi za ravnopravnost $\mathrm{i}$ izobrazbu žena. U njezinom književnom radu odražavaju se kršćanstvo i idealizam proizašli iz obiteljskog odgoja, te iskreno i plemenito domoljublje (Hranjec, 2006: 51-56; Crnković i Težak, 2002: 288-310). ,Jagoda Truhelka primjer je autora koji svoje duboko proživljavanje stvarnosti umije pretočiti u jednostavan i dojmljiv, sugestivan i poetičan govor, priču koja prividno nikada ne počinje i neće prestati, omeđena tek rubovima samoga života. Njeni su likovi svakodnevni, a opet osobiti, unikatna bića, duše koje ispisuju svoje sudbine kroz njeno nadahnuto pero i kojima baš njena pozornost pridaje dah neponovljive osobnosti” (Lovreković, 1998: 41). Cijeli je život Jagode Truhelke bio ovisan o književnom radu i učiteljskom pozivu čiji se korijeni skrivaju u njezinom obiteljskom domu (Pilaš, 1998). Iako je napisala i druga književna i pedagoška djela, autori Milan Crnković i Dubravka Težak naglašavaju kako je „Jagoda Truhelka ipak i prije svega autorica Zlatnih danaka” (2002: 293).

\section{Književna trilogija Zlatni danci}

Čitavo Truhelkino vrijedno književno stvaralaštvo za djecu objavljeno je između dva svjetska rata i tijekom Drugog svjetskog rata, od 1918. do 1944. godine. Započelo je izlaskom prvoga izdanja romana Zlatni danci, prvog dijela istoimene

\footnotetext{
${ }^{2}$ Ivo Zalar (1978) i Joža Skok (1991) smatraju roman Čudnovate zgode šegrta Hlapića Ivane BrlićMažuranić, prvi put objavljen 1913. godine, jednim od prvih hrvatskih dječjih romana. Međutim Berislav Majhut opovrgava tezu o ovom romanu kao prvom hrvatskom dječjem romanu u studiji Pustolov, siroče i dječja družba: hrvatski dječji roman do 1945. (2005) u kojoj donosi popis dječjih romana objavljenih prije 1913. godine, s trideset i dva naslova koja se mogu smatrati dječjima romanima. U ovaj popis uvršteni su primjerice romani Tugomila Jagode Truhelke, Sretni kovač Vjekoslava Koščevića te dva romana Davorina Trstenjaka, Savka i Stanko i U radu je spas. Majhut kao svoje polazište za teorijsko određenje dječjeg romana uzima naratološku kategoriju implicitnog čitatelja te time mijenja sliku o stanju hrvatskog dječjeg romana, koja se očituje u trima strukturno tematskim modelima dječjih romana - u pustolovnom romanu, u romanu o siročetu i u romanu o dječjoj družini (Majhut, 2005).
} 
književne trilogije, 1918. godine. Potom su nastala dva romana koja je Jagoda Truhelka pridružila prvom, Zlatnim dancima - Bogorodičine trešnje (1929) i Dusi domaćeg ognjišta (1930). Godine 1944. objavljen je roman Crni i bijeli dani te je, spojivši drugu i treću knjigu, Truhelka umjesto tetralogije svoje romane podijelila u trilogiju (Crnković i Težak, 2002)3.

Prema riječima Ane Pintarić: „Svijet u zbirci Zlatni danci pravi je dječji svijet u kojemu su glavni likovi stvarna djeca prepoznatljiva po postupcima, igri, maštanju i govoru, djeca s čijeg je gledišta i opisano djetinjstvo u Osijeku u drugoj polovici 19. stoljeća" (2004: 21). Glavni likovi Zlatnih danaka jesu djeca - Anica, Ćiro i Dragoš, troje djece koja svojim prisustvom povezuju fabule triju romana. Fabula književne trilogije Zlatni danci ispripovijedana je u trećem licu te govori o djetinjstvu jedne sestre i dvojice braće. Lik djevojčice Anice predstavlja samu autoricu Jagodu Truhelku koja opisuje vlastito djetinjstvo. Stoga su Zlatni danci ujedno i autobiografsko djelo. Pišući o Truhelkinoj književnoj trilogiji u kontekstu rasprave o autobiografizmu, Andrijana Kos Lajtman ističe kao najzanimljiviju činjenicu to što se: ,pripovijeda u trećem licu te (što) pripovjedačica glavni lik imenuje Anicom, a ne Jagodom, dok dvojici Aničine braće pridaje imena koja su i u stvarnosti nosila Truhelkina braća" (2011: 129). Riječ je o tekstu: „koji balansira u procijepu između onog što Genette naziva heterodijegetskom autobiografijom, što je rijedak slučaj autobiografije pisane u trećem licu, gdje postoji identitet autora i lika, ali niti jedan od njih nije identičan pripovjedaču, i heterodijegetske fikcije gdje ni jedan element trijade nije identičan bilo kojem od dva preostala elementa" (Kos Lajtman, 2011: 133).

Kao mjesto radnje Truhelka opisuje svoj rodni grad Osijek, preciznije Labudovu ulicu odnosno ulicu u kojoj je odrastala te Donji i Gornji grad, Tvrđu i Novi grad. Osim toga, kao mjesta radnje pojavljuju se bakino selo Ladimirevci i Aljmaš, te Hrvatsko zagorje (Pintarić, 2004). Upravo zbog vjerodostojnog i ljubavlju ispunjenog opisa Osijeka, Truhelka je prozvana osječkim Šenoom budući da je Šenoa, poput nje, istom ljubavlju opisivao svoj Zagreb (Hranjec, 2004). Šenoin se utjecaj može primijetiti i u opisu likova - građana Osijeka. „Osijek i njegova spisateljica kao da su se međusobno darivali: ona je fiksirala njegovu sliku, izgled njegovih ulica i kuća, vrtova, poljana, vojničkih vježbi i dječjih igara, blata i prašine, majstora i trgovaca, a on je opet pridonio uvjerljivosti, autentičnosti i životnosti radnje njenih pripovijedaka" (Crnković i Težak, 2002: 296).

Djeca u Truhelkinim Zlatnim dancima ovise o svojim roditeljima i ostalim odraslima, vezana su za njih te se, ako izmaknu njihovoj pozornosti, nađu u raznim neprilikama. „Svijet djece i odraslih u Truhelkinim su tekstovima čvrsto isprepleteni i jedna strana ne može drugoj pobjeći, i ako nisu slobodni jedni, nisu slobodni

\footnotetext{
${ }^{3}$ Kao što piše Ana Pintarić, često se postavljalo pitanje jesu li dijelovi trilogije Zlatni danci romani ili zbirke pripovijedaka. Promatra li se opširnost djela, može se reći da se radi o tri romana s ukupno 1112 stranica. Međutim, promatraju li se sve tri knjige koje su zapravo sastavljene od zaokruženih i povezanih epizoda, Zlatni danci mogu se okarakterizirati i kao zbirka pripovijedaka (Pintarić, 2004). Autorice ovog rada opredjeljuju se za odrednicu dječji roman s obzirom na to da se Jagoda Truhelka u kontekstu znanstvenih istraživanja hrvatske dječje književnosti prepoznaje kao jedna od začetnica hrvatskoga dječjega, posebice obiteljskoga romana (usp. Hranjec, 2009).
} 
ni drugi" (Crnković i Težak, 2002: 298). No, važno je napomenuti da Truhelkini dječji likovi, iako odgajani u obiteljskoj zajednici te vezani za svijet odraslih, nisu podređeni odraslima, već su „samosvojne i uvjerljive osobnosti” (Kos Lajtman, 2011). Živeći kao skladna cjelina, Stjepan Hranjec (2004) naglašava da se djelići njihovih života nadopunjuju i isprepliću te fabulu čine životnijom i uvjerljivijom. Upravo zato je ova Truhelkina književna trilogija zauzela posebno mjesto u hrvatskoj dječjoj književnosti. Prikazavši ugođaj obitelji, život djece i njihove svakodnevne radosti Truhelka je uspjela približiti svoje romane djeci čitateljima: „Nižući trenutak po trenutak vremena zgusnutog u šutnji koja se počinje pretvarati u šapat olovke, a zatim sve radosnije kliktaje, ona nas vodi u skrivene svjetove svačijeg života" (Gjerek Lovreković, 1998: 42).

\section{Slika obitelji u književnoj trilogiji Zlatni danci}

Jagoda Truhelka odrasla je u učiteljskoj obitelji čije su temeljne vrijednosti bile obiteljski sklad, odgoj u duhu kršćanstva i vjera, tradicija i domoljublje, te međupovezanost dječjih i odraslih članova obitelji. Ove vrijednosti Truhelka prenosi u svoje književno stvaralaštvo, posebice u svoju autobiografsku književnu trilogiju Zlatni danci te se na njima kao sastavnim komponentama, temelji ovdje predstavljena analiza slike obitelji u Truhelkinim dječjim romanima.

\subsection{Obiteljski sklad}

Prema riječima Ane Pintarić, u književnoj trilogiji Zlatni danci polazi se od osnovne komponente - obiteljskog sklada. Anica, Ćiro i Dragoš imali su prigodu odrasti u obitelji koja pruža ljubav i sve one dobre, blage i radosne trenutke koje bi svako dijete trebalo osjetiti i proživjeti. Naučili su da se i na zemlji može živjeti kao u raju ako prihvaćaš čovjeka s ljubavlju (2005). Veliku ulogu u odgoju djece te cjelokupnom funkcioniranju ima otac, po zanimanju učitelj, koji svoj pedagoški rad usmjerava i na odnos sa svojom djecom. Aničini roditelji neprestano se trude da njihova djeca budu sretna, da im ne nedostaje ljubavi, ali i da poštuju i cijene jedni druge. Zlatni danci oslikavaju čvrsto strukturiranu, homogenu obitelj odnosno književničino djetinjstvo čime ona ističe važnost obitelji i njezinog skladnog funkcioniranja.

Jagoda Truhelka prikazuje brojne situacije u kojima se može zamijetiti sklad obitelji, poput dugih zimskih večeri u kojima su djeca posebno uživala:

„Iza večere je. Oko stola se skupila sva porodica. Pred majkom leži hrpa haljinica i čarapa što su ih nestašna djeca preko dana isparala i poderala. Majka krpa i popravlja kvarove kako najbolje zna. Kraj nje sjedi Anica jer joj svaki čas treba to majčinih škara, to žice konca. Krilo joj je puno krpica što ih je sretna podobivala i od mame i od maminih znanica, i od krojačica i od kitničarica. Pa sad blaženo prekapa po tom blagu od svile i čipaka slažući prekrasne haljine i šešire za mnogobrojnu svoju lutčiju porodicu. Uz nju se po stolu raširio Ćiro. Pred sobom razastro daščice 
pa dube, reže, pili i vrti. (...) Baka kraj peći sjedi na niskom stočiću plete čarapu 'napamet' kako bi Ćiro kazao, jer plete da i ne gleda u pletivo (...) staračke oči zaokruže dalje i po sobi i po čeljadi u njoj kao da broje jesu li svi na okupu. Najposlije se ustave na Dragoša koji je čučao na podu do bakinih nogu i postavljao olovne vojnike u bojne redove. (...) Dragoš se zaleti ocu pa njemu na koljeno. Podlakti se ručicom na stol i pun očekivanja gleda na crnu tablicu što će to tata na njoj 'napisati'. Sve je tiho. Čas pô samo zveckaju škare u maminoj ili Aničinoj ruci, u Ćirinoj čekić, u peći praskaju drva, na Dragoševu se krevetku smotao mačak u klupko pa slatko prede, a iz kuhinje kroz staklena vrata čuje se tihi mrmor Kristine koja čisti cipele i Bogu se moli" (Truhelka, 2004: 103).

Autorica prikazuje idiličnu zimsku večer svoje obitelji u kojoj vlada sklad i ispunjenje. Svatko pronalazi zadovoljstvo u kutku svoga doma, a prizor pritom odiše srećom i zajedništvom.

\subsection{Kršćanski odgoj u obitelji}

Sljedeća važna komponenta je spoj kršćanskog odgoja i vjere te tradicije $\mathrm{i}$ činjenja dobrih djela. Vjera u Truhelkinim Zlatnim dancima snažno utječe na oblikovanje Aničinog života u obitelji određujući tijek zbivanja. Vjerska načela u Aničinoj obitelji predstavljala su putokaz u odgoju, odnosno civilizacijsko nasljeđe u kojemu najveću odgovornost imaju roditelji koji čvrsto drže spone svoje obitelji (Hranjec, 1998). Kršćanstvo i kršćanski odgoj posebno se mogu zamijetiti u poglavljima u kojima fabula uključuje najvažnije vjerske blagdane poput Božića, Uskrsa, Velike Gospe ili kršćanskih običaja, hodočašća i procesija. Truhelka u fabulu uključuje svakodnevnu molitvu Bogu na kraju dana, odlazak u crkvu s obitelji te pjevanje vjerskih pjesama kako bi naglasila kršćansko ozračje koje vlada u obitelji i odgoj temeljen na tom ozračju. Uz vjeru, posebno mjesto u Truhelkinim Zlatnim dancima zauzima i tradicija koja se očituje u tradicijskim običajima slavljenja Božića i drugih blagdana ili primjerice u obiteljskom hodočašću u Aljmaš.

U poglavlju Stari glasovir Truhelka opisuje obiteljsko ozračje u kojemu peteročlana obitelj s bakom dočekuje Maloga Isusa. U obiteljskom domu prevladava svečano i blagdansko ozračje, a djeca su posebno nestrpljiva jer jedva čekaju što će im donijeti novorođeni Isus: „Tako osvane i Badnjak. Kuća se svečano opremila, sva miriše borovinom, kolačima i svakojakim dobrom. Iza večere nekamo nestalo tate, a dječaci se skupili oko mame i bake kraj Aničina kreveta pa sve strepe od nestrpljivosti, radoznalosti i očekivanja. (...) Stoje djeca na pragu, gledaju u sjajno rasvijetljeni bor i pjevaju. Još ne vide dječaci ništa drugo do svjećica na drvcetu. Ali Anica sa svoga krevetka odmah spazi drugu jednu stvar, veliku i sjajnu, za njom sjedi tata i izvija iz nje divne pjesme što ih djeca redom pjevaju: Narodi nam se kralj nebeski / Od Marije čiste djevice" (Truhelka, 2004: 94-95).

Književnica naglašava i važnost činjenja dobrih djela. Raznim majčinim postupcima uočava se njezina želja da djeca odaberu ispravan životni put. Aspekt dobrih djela Truhelka snažno ističe primjerice u poglavlju Još jedan Božić u kojem Anica shvaća što znači biti siromašan i gladan, pa žrtvuje jedan svoj obrok i igračke 
kako bi razveselila siromašnu obitelj tete Reze. Majka je bila sretna što je odvela Anicu u siromašnu četvrt jer je: „ćutjela da joj se jedinica danas sretno zaputila stazom po kojoj ju je htjela povesti u život" (Truhelka, 204: 180). Djeca su učila živjeti nesebično, drugima pomagati i suosjećati s njima, a što je najvažnije činiti dobra djela, svakom zlu dobrom vratiti.

\subsection{Domoljublje}

Neizostavna komponenta Truhelkine književne trilogije jest domoljublje koje je bilo prisutno u obitelji u svakidašnjim pripovijedanjima priča, ali i u dječjim igrama. Otac je bio onaj koji je imao najvažniju ulogu u širenju ljubavi prema domovini. U njegovim se pričama, od povijesnih ličnosti, najviše isticao Nikola Zrinski kao simbol hrvatske hrabrosti i junaštva. Posebno mjesto u očevim pripovijedanjima djeci imao je i ban Josip Jelačić. Komponentu domoljublja Truhelka uvodi u opis obiteljske interakcije između djece i roditelja kroz koju se saznaje o hrvatskoj povijesti. Ljubav prema domovini odrasli su htjeli prenijeti na svoju djecu što se može primijetiti u poglavlju Zimske večeri. Na nagovor maloga Dragoša, tata je pripovijedao o Jelačiću banu, Nikoli Zrinjskom i o drugim junacima koji su se borili za domovinu te je dodao: „Tako trebate i vi, djeco moja, ljubiti i raditi za svoju domovinu Hrvatsku” (Truhelka, 2004: 107).

\subsection{Međuzavisnost djece i odraslih}

Kao posljednja komponenta izdvaja se dječja i roditeljska međuzavisnost koja se očituje u trenutcima obostrane brige članova obitelji jednih o drugima te $\mathrm{u}$ zapadanju djece u neprilike u situacijama u kojima roditelji nisu prisutni. Djeca su vezana za roditelje i svijet odraslih, ali ipak reagiraju prema svojim interesima ponašajući se kao djeca (Hranjec, 1998). Truhelka Aničinu obitelj gradi na elementima etičkog kodeksa što znači da postoje pravila i dužnosti unutar obitelji i u odgoju djece. Ipak, djeca bez prisustva roditelja zapadaju u iskušenja te zbog svoje radoznalosti i zaigranosti dolaze u opasnost. Roditelji su zaštitnici svoje djece te ih spašavaju u trenutcima kada ona sama nisu za to sposobna. Njihov je zadatak da brinu o svojoj djeci te spriječe nepoželjne situacije poput igranja djece nožem, barutom ili vatrom. Osim majke i oca, posebno mjesto u obitelji imala je i sluškinja Kristina: „bogobojazna iskrena vjernica koja u svakodnevnim događajima prepoznaje Božje djelo" (Pintarić, 2005: 146). Aničini roditelji veoma su je voljeli i poštovali te su je prihvatili kao članicu obitelji. Kristina nije samo obavljala kućanske poslove, već je i brinula o djeci te ih je, uz roditelje, i odgajala, čega je primjer i ulomak iz poglavlja U Labudovoj ulici: „A to je Ćiro bio izuo cipele, pa bosonog do koljena gazio po debelom blatu, a Dragoš, derančić u suknjici, sjedio na kraju ceste, mijesio kolače pa ih oko sebe hitao ne mareći kud će koji pasti. Pri tom se poslu ljudski i oznojio, znoj se izmiješao s blatom, a tragovi te smjese zaostali mu po svem tijelu i odijelu. Pritrča Kristina, digne se i zajauče: Što će mama ako te takova vidi? A ti, Ćiro, odmah da uđeš u kuću pa da znaš, dobra biti neće! (...) 'Kristina, nemoj nikome kazati', moljaše on, 'oprat ću se pa neće nitko znati'. A dobra Kristina sve karajući i psujući 
umije ih i očisti koliko se dalo, obuje ih i opet uredi (...). Ali mama je ipak saznala pa je onda bilo svašta. A da se ne bi ponovilo, dao tata dovesti veliku hrpu pijeska u dvorište, i tu se sada kopalo i gradilo, vrtali se rovovi i podrumi, šančevi i prokopi, gradile kuće i mostovi” (Truhelka, 1969: 7).

Jagoda Truhelka u književnoj je trilogiji Zlatni danci prikazala svoje djetinjstvo idilično, onakvo kakvoga se ona sjećala. Njezino je odrastanje u obitelji bilo sretno jer joj je pružilo sve što svako dijete zavrjeđuje: ljubav, pažnju, osjećaje sigurnosti i pripadnosti, te nježnost i poštovanje. Kao što zaključuje Stjepan Hranjec: „To je trilogija koja je na najplemenitiji način afirmirala dom i obitelj, gdje nema strogoće ni obiteljskih drama nego se tu život odvija po etičkim načelima sazdanim na kršćanskim istinama, zato taj dom zrači toplinom i ljubavlju” (2004: 26).

\section{Zaključak}

Slika obitelji u velikoj je mjeri zastupljena u hrvatskoj dječjoj književnosti. Bilo da se radi o obiteljskom romanu ili motivu obitelji u dječjem romanu, $u$ književnim se djelima namijenjenim djeci mogu se uočiti i analizirati različiti pristupi obitelji i njezinim članovima. Već u mlađoj školskoj dobi djeca čitatelji susreću se s književnim tekstovima u kojima mogu prepoznati karakteristične slike obitelji.

Jagoda Truhelka, kao jedna od začetnica hrvatskoga dječjega, posebice obiteljskoga romana, u književnoj trilogiji Zlatni danci predstavila je sliku obitelji čija su obilježja obiteljski sklad, odgoj djece u kršćanskom duhu, plemenito domoljublje te međuzavisnost djece i roditelja. Uvodeći lik Anice koja predstavlja samu autoricu, lik Ćire i Dragoša, majke i oca te sporednih likova, Truhelka je opisala svakodnevne trenutke koje je proživljavala njezina obitelj. U toj je obitelji bio bitan svaki razgovor, svako pripovijedanje, svaka igra, svaka radost i tuga. Iako pripada realističnom stvaralaštvu, Truhelka u svoju zbirku uvodi elemente idealizacije odnosno sliku obitelji koja je i koja bi trebala biti primjer svakoj obitelji. Ta se slika temelji na dobroti, poštovanju, ljubavi, brizi, razumijevanju, vjeri i ljubavi prema domovini. Promicanjem pozitivnih ljudskih vrijednosti, Truhelka je željela naglasiti važnost odgoja djece i njihovog usmjeravanja na pravi životni put. Uz roditelje, ulogu u dječjem odrastanju imale su i druge osobe - članovi šire porodice i kućanstva, koje su svojim djelovanjem oblikovale Aničinu obitelj.

S obzirom na to da je dječji roman sastavni dio dječje književnosti te je samim time namijenjen recipijentima dječje dobi, slika obitelji u ovom žanru sadrži veliku vrijednost za male čitatelje. Prepoznajući obilježja različitih obitelji koje se opisuju u dječjim romanima, djeca uče prepoznati pozitivne vrijednosti koje obitelj može (i trebala bi) promicati, ali isto tako uočavaju i određene nepravilnosti i probleme unutar obitelji, koje danas sve više susrećemo u suvremenom društvu. Ujedno, dijete čitatelj se, upoznavši obitelj i obiteljske odnose u pojedinom dječjem romanu, može poistovjetiti s dječjim književnim likovima te lakše razumjeti pa i podnijeti stanje u vlastitoj obitelji. Važno je da svako dijete odrasta u zajednici koja će mu pružiti sretno djetinjstvo ispunjeno ljubavlju i osjećajem pripadnosti, prihvaćenosti 
i sigurnosti, uz koju će zadovoljiti svoje potrebe i interese te stasati u dobru odraslu osobu. Književna trilogija Zlatni danci Jagode Truhelke zasigurno tome i danas daje veliki doprinos.

\section{Literatura}

Bošković, I. J. (2005). Obitelj u književnosti za djecu i mladež: tema obitelji u dječjoj književnosti. U: A. Pintarić (ur.). Zlatni danci 7 (19-25). Osijek: Filozofski fakultet.

Crnković, M. i Težak, D. (2002). Povijest hrvatske dječje književnosti od početka do 1955. godine. Zagreb: Znanje.

Gjerek Lovreković, M. (1998). Rajski trenuci djetinjstva. U: J. Martinčić i D. Hackenberger (ur.). Zlatni danci: život i djelo Jagode Truhelke (41-44). Osijek: Hrvatska akademija znanosti i umjetnosti.

Hameršak M. i Zima D. (2015). Uvod u dječju književnost. Zagreb: Leykam international, d.o.o.

Hranjec S. (1998). Hrvatski dječji roman. Zagreb: Znanje.

Hranjec S. (2004). Dječji hrvatski klasici. Zagreb: Znanje.

Hranjec S. (2006). Pregled hrvatske dječje književnosti. Zagreb: Školska knjiga.

Hranjec S. (2009). Ogledi o dječjoj književnosti. Zagreb: Alfa.

Janković, J. (2004). Pristupanje obitelji. Zagreb: Alinea.

Kos Lajtman, A. (2011). Autobiografski diskurs djetinjstva. Zagreb: Naklada Ljevak.

Majhut, B. (2005). Pustolov, siroče i dječja družba: hrvatski dječji roman do 1945. Zagreb: FF Press.

Maleš, D. (2012). Obitelj i obiteljski odgoj u suvremenim uvjetima. Dijete, vrtić, obitelj, 18(67), 13-15.

Pilaš, B. (1998). Rajski trenuci djetinjstva. U: J. Martinčić i D. Hackenberger (ur.). Zlatni danci: život i djelo Jagode Truhelke (149-154). Osijek: Hrvatska akademija znanosti i umjetnosti.

Pintarić, A. (2004). U svjetlu interpretacije: Zlatni danci Jagode Truhelke. Osijek: Filozofski fakultet.

Prodan, J. (2005). Obitelj u književnosti za djecu i mladež: položaj djeteta u obitelji. U:

A. Pintarić (ur.). Zlatni danci 7 (7-17 ). Osijek: Filozofski fakultet.

Skok, J. (1991). Prozori djetinjstva (I). Antologija hrvatskog dječjeg romana. Zagreb:

Naša djeca.

Truhelka, J. (1969). Zlatni danci. Zagreb: IKP Mladost.

Truhelka, J. (2004). Zlatni danci. Zagreb: Znanje.

Vrcić-Mataija, S. (2018). Hrvatski dječji realistički roman (1991-2001). Zadar:

Sveučilište u Zadru.

Zalar, I. (1978). Dječji roman u hrvatskoj književnosti. Zagreb: Školska knjiga. 


\title{
THE IMAGE OF THE FAMILY IN THE LITARY TRILOGY GOLDEN DAYS (ZLATNI DANCI) BY JAGODA TRUHELKA
}

\author{
Maja Verdonik, Josipa Kovač \\ University of Rijeka, Faculty of Teacher Education Republic of Croatia
}

\begin{abstract}
With an insight into the theoretical determinants of the children's novel and the theme of the family in the Croatian children's novel, the paper presents the importance and role of the family in the literary trilogy Golden Days (Zlatni danci), written by one of the founders of Croatian children's realistic prose, Jagoda Truhelka. The aim of the paper is through analysis of the available scientific sources and literary texts to present the literary motifs present in describing the image of the family in the literary trilogy Golden Days (Zlatni danci). Jagoda Truhelka introduces readers to her idyllic childhood, which is characterized by family harmony, the Christian spirit in raising children, patriotism and the interdependence of children and parents. These are the values on which, as constituent components, the analysis of the image of the family in Truhelka's children's novels, presented in the paper, is based. The literary trilogy Golden Days (Zlatni danci) depicts a tightly structured, homogeneous family in which the father-teacher played a major role. Religious principles were a guide in the upbringing of children, based on Christian principles also present in the descriptions of religious holidays and customs. Nurturing patriotism is evident in everyday storytelling and children's games, with the father once again being the one who played the most important role in it. Child and parental interdependence are present in the constant care of family members for each other, especially in moments of children getting into trouble in situations where parents were not present. Growing up in Jagoda Truhelka's family was happy because it gave the children what every child deserves: love, attention, feelings of security, belonging, tenderness and respect. The image of such a family, presented in the literary trilogy Golden Days (Zlatni danci), certainly still contributes to the upbringing of today's children.
\end{abstract}

Key words: Jagoda Truhelka, Golden days (Zlatni danci), Croatian children's novel, family in children's literature

Citiranje članaka: Verdonik, M. i Kovač, J. (2020). Slika obitelji u književnoj trilogiji Zlatni danci Jagode Truhelke. Godišnjak za pedagogiju, 5(1), 23-33. 